\title{
IDENTIFICATION OF VECTOR SPECIES (DIPTERA: SIMULIIDAE) OF HUMAN ONCHOCERCIASIS IN THE AMAZONIA FOCUS OF BRAZIL AND VENEZUELA
}

\author{
A.J. SHELLEY* ,A.P.A. LUNA DIAS**, M. MAIA-HERZOG***,W.S. PROCUNIER * \& M.A.P. \\ MORAES *** \\ * Department of Entomology, Bristish Museum (Natural History), London, U.K. (World Health Organization \\ Collaborating Centre for the study of Simuliidae and Phlebotominae in relation to Onchocerciasis and \\ Leishmaniasis) ** Instituto Oswaldo Cruz, Departamento de Entomologia, Caixa Postal 926, 20001 Rio de \\ Janeiro, RJ, Brasil ${ }^{* *}$ Departamen to de Medicina Complementar, Faculdade de Ciências de Saúde, Universidade \\ de Brasília, DF, Brasil
}

The taxanomic status of three Amazonian simuliid species, Simulium guianese Wise, S. oyapockense Floch \& Abonnenc and S. yarzabali Ramirez Perez is reviewed. Simulium cuasisanguineum Ramirez Perez, Yarzabal \& Peterson is synonymized with S. oyapockense, and S. yarzabali is revalidated from its synonymy with $\mathrm{S}$. incrustatum $L u t z$. The role of these three species in the transmission of human onchocerciasis and mansonelliasis in Amazonia is reviewed.

Key words: Simuliidae - vector species onchocerciasis - Amazonia

Since Goeldi's original description of $S$. amazonicum in 1905 from material collected in the Brazilian Amazon this species has been the most misidentified simuliid in the region. Interest in $S$. amazonicum and other black fly species grew when simuliids rather than ceratopogonids were suspected as vectors of Mansonella ozzardi from Cerqueira's work (1959) and later confirmed as vectors in both Brazil (Shelley et al., 1980) and Colombia (Tidwell et al., 1980). Recent work in Brazil (Shelley et al., 1979b) and Venezuela (Rassi et al., 1977) also implicated a simuliid species related to $S$. amazonicum as vector in the Amazonia onchocerciasis focus. A persistent problem during work on the transmission of these humuil filariae has been the difficulty in accurately identifying the simuliid vector species.

It is now clear (Shelley et al., in press) that there are at least two main vectors of Onchocerca volvulus in the Amazonia focus of northern Brazil and southem Venezuela. Simulium guianense Wise in the highland areas and $S$. oyapockense Flock \& Abonnenc in lowland localities, as well as a potential third vector variously identified as $S$. limbatum Knab. S. incrustatum Lutz or $S$. yarzabali Ramirez Perez that also mainly occurs in highland localities. Considerable difficulty has been encountered in distinguishing $S$. guianense from closely related taxa in the $S$. guianense group and the latter three species from their relatives in the $S$. amazonicum group.

linancial assistence for the field work was provided by SLCAM, the Oswaldo Cruz Institute, Rio de Janciro, and the Pan American Health Organization. Received March 5, 1987.

Accepted April 14, 1987
Misidentifications of this fauna has occurred primarily for two reasons. First, the area in which these species occur had been poorly prospected prior to the discovery of the onchocerciasis focus nearly twenty years ago resulting in the simuliid fauna being superficially studied and described. Consequently, characters that were thought to be species diagiostic are now seen to be polymorphic as a result of population sampling from a broader geographic range. Secondly, the lack of an in tegrated study by workers in the focus has resulted in the publication of a profusion of new names from Venezuela for already described morphospecies. In order to facilitate identification of these vector species and their relatives this paper attempts to clarify their taxonomic status by discussing the relevant literature.

\section{Simulim guianense Wise}

Identification of the highland vector is difficult because the females of three species, $S$. guianense Wise, $S$. pintoi d'Andretta \& d'Andretta and $S$. orbitale Lutz are morphologically very similar. The last two species are easily separated from one another on pupal gill filament number and configuration and also on nale scutal patterns, but $S$. guianense is not reliably known in the pupa or male having been described from anthropophilic females collecied in Guyana (Wise, 1911).

In the onchocerciasis focus in Brazil biting females identical to the types of both $S$. pintoi and $S$. guianense were collected and judged to be conspecific with females reared in localities where the speries is totally zoophilfc. In Venezuela this species is regarded as $S$. pintoi (Ramirez Pere:, 1983, 1984, 1985, 1986; Ramirez 
Perez et al., 1982; Rassi \& Monzon, 1981; Rassi et al., 1977; Tada et al., 1983 and Takaoka et al., 1984) and is found both within and to the north of the focus. Ramirez Perez (1971) described material from the state of Bolivar, outside the focus, as a new species $S$. ortizi but later (Ramirez Perez et al., 1982) synonymized this name with $S$. pintoi. In Brazil Rassi (1974) identified $S$. guianense as $S$. pintoi and $S$. orbitale. It was then cited as Simulium species B by Shelley et al. (1976) and later identified as either $S$. pintoi or $S$. guianense in Moraes et al. (1979). In 1979 Shelley et al. referred to this species as $S$. guianense which was later misquoted as $S$. pintoi $($ ? = guianense $)$ in Tidwell et al. (1981).

We prefer to use the name $S$. guianense because it predates that of $S$. pintoi. $S$. guianense is a well known anthropophilic species in western Guyana, whereas $S$. pintoi is generally regarded as a zoophilic species of large rivers of Amazonia and Southern Brazil. The relation. ship between these two species will be further investigated using morphological and cyto. logical methods when males, pupae and larvae of $S$. guianense are obtained from the type locality for comparison with the $S$. pintoi types.

\section{Simulim oyapockense Floch \& Abonnenc}

This species was first described by Floch \& Abonnenc (1946) from the River Oyapock between Brazil and French Guiana. It remained a relatively little known species until Shelley and co-workers (World Heal th Organization, 1982) discussed its taxomic status and relationship with onchocerciasis transmission in the Amazonia focus. Misidentifications of the lowland vector species $S$. oyapockense from the Brazilian side of the focus had occurred before 1984 when Shelley et al. were able to clarify the situation based on better material in the form of reared topotypes. Shelley et al. (1982) had provionally assigned the vector species at Toototobi to $S$. minusculum Lutz, after examining the syntype series of this species and suggested a possible synonymy with $S$. roraimense. However, the syntype series was then shown (Shelley et al., 1984) to include a second species, $S$. oyapockense with which the primary vector species at Toototobi was considered to be conspecific. Variations in adult scutal pattern and in pupal gill length and configura. tion were noted in relation to the female lectotype and reared topotypes of $S$. oyapockense. Furthermore, $S$. roraimense was also regarded as distinct from $S$. minusculum but a close relative of $S$. oyapockense being distinguishable only in the male. Py-Daniel (1983) working independently arrived at the same conclusion with reference to the taxonomic status of these three species.

In Venezuela three nominally new species, $S$. pseudosanguineum, $S$. sanchezi and $S$. cuasisanguineum were described and keys to the simuliid fauna of Amazonas Territory of Venezuela, in which the onchocerciasis focus lies, were given by Ramirez Perez \& Peterson (1981) and Ramirez Perez et al. (1982). Of the three species only $S$. sanchezi is not recorded in the onchocerciasis focus by these authors. In 1983, $S$. pseudosanguineum was accepted as a synonym of $S$. oyapockense by Ramirez Perez as was originally proposed by Shelley and co-workers (World Health Organization, 1982) and further detailed in Shelley et al. (1984). The latter authors at the same time synonymised $S$. sanchezi with $S$. oyapockense but reserved judgement on the taxanomic status of $S$. cuasisanguineum.

The vector status of these new nominal species has been referred to by Ramirez Perez in several publications. $S$. cuasisanguineum is cited (Ramirez Perez, 1983, 1984, 1985, 1986; Ramirez Perez et al., 1982) as the vector of onchocerciasis both in Venezuela and in Brazil based on material from Rassi's earlier collections described in Rassi et al. (1977, 1978). This assessment is inaccurate because although Ramirez Perez et al. (1982) correctly accept that $S$. roraimense Nunes de Mello and S. cuasisanguineum are inseparable in the female they base their identification of the latter species on reared material collected outside the onchocer. ciasis focus at Tama Tama. It is therefore questionable how such a precise identification of wild females of the species incriminated as a vector could be made when no reared material was collected by Rassi that could be associated with these adults.

A further complication arises over the identification of the filiarial larvae. Ramirez Perez (1983), states that the infective larvae [ only one reported by Rassi et al., 1977, 1978] from Rassi's work in Venezuela are probably of Mansonella ozzardi but later the same author (Ramirez Perez, 1984, 1985, 1986) citics them as $O$. volvulus.

We have now re-evaluated the existence of variation in granulosity in pupal integuments of various species in the $S$. amazonicum group and now regard the lack of granulations on the frontoclypeus and the reduced number on the thorax of the pupa as insufficient on their own to warrant the creation of a new taxon. Consequently $S$. cuasisanguineum is he re synonymised with $S$. oyapockense. Integrated cy.tological and morphological studies currently underway may clarify whether such morfophological charac- 
teres are of greater importance as diagnostic criteria for species identification.

We therefore accept the existence of a polymorphic species $S$. oyapockense with a wide distribution in the upper Amazon and Orinoco basins and in the Guianas in which variations exist in scutal pattern and leg colouration of the adults, and gill iength, form and in tegument granulosity of the pupae. Formal naming of species based on these variations is considered premature until specific morphological characters can be linked to chromosomal differences in specimens reared from single egg batches or from adults reared from pupae from cytospecies-pure localities. In support of this approach is recent taxanomic work on the $S$. damnosum complex in West Africa. Male scutal patterns, which were supposedly diagnostic for separating six of the cytospecies of $S$. damnosum (Dang \& Petterson, 1980) have subsequently been found to exhibit considerable in traspecific variation when integrated morphological and cytological studies on adults reared from single egg batches of two of the cystopecies were carried out (Meredith et al., 1983).

This interim action of synonymy of the three species proposed by Ramirez Perez means that only two common anthropophilic species, $S$. oyapockense and $S$. roraimense. are now recorded for Amazonia in place of the previous five. Since females of the two species are indistinguishable it is not known whether both are vectors of onchocerciasis in the lowland areas of the Amazonia focus. Similarly, S. oyapockense or $S$. roraimense is also the vector of $M$. ozzardi in Guyana (Nathan et al., 1982 as $S$. minusculum) Brazil (Moraes et al., 1985) and Venezuela (as $S$. sanchezi, Ramirez Perez et al., 1982; Yarzabal et al., 1983; as $S$. sanchezi and $S$. amazonicum in Ramirez Perez, 1983) and Colombia (Tidwell et al., 1980 as unnamed member of the $S$. sanguineum [ = $S$. amazonicum ] group).

Table lists names previously used for $S$. oyapockense.

\section{Simulium yarzabali Ramirez Perez}

Identification of this species has been problematical and its taxonomic status has still not been adequately resolved. Rassi (1974) first identified this species as $S$. incrustatum Lutz from two localities on the Brazilian side of the Amazonia onchocerciasis focus. Later Moraes et al. (1979) cited $S$. incrustatum as a potential vector of either onchocerciasis or mansnnelliasis at one of these localities, Auaris, because wild caught flies contained sausage stage filariae. Ramirez Perez (1980) then described a new species, $S$. yarzabali from material collected at a highland locality on the Venezuelan side of the focus. We have examined this material and judge it to be conspecific with Amazonian $S$. incrustatum sensu Rassi (1974), sensu Moraes et al. (1979), but not with $S$. incrustatum from southern Brazil from where the species was first described.

\section{TABLE}

List of previous names used for $S$. oyapockense

\begin{tabular}{|c|c|c|}
\hline Identification & Country & Source \\
\hline $\begin{array}{l}\text { S. amaronicum complex } \\
\text { (amazonicum }+ \text { minusculum })^{*}\end{array}$ & Brazil & Rassi, 1974 \\
\hline S. amazonicum* ${ }^{*}$ & $\begin{array}{l}\text { Brazil } \\
\text { Venezuela }\end{array}$ & $\begin{array}{l}\text { Moraes et al., 1979; Rassi et al., } 1975 \text { a, b. } \\
\text { Ramirez Perez, 1983; Rassi \& Monzon, } 1981 \text {; } \\
\text { Rassi et al., } 1977,1978 .\end{array}$ \\
\hline S. cuasisanguineum syn. n. & $\begin{array}{l}\text { Venezuela } \\
\text { Brazil }\end{array}$ & $\begin{array}{l}\text { Ramirez Perez et al., } 1982 \\
\text { Ramirez Perez, 1983, 1984, 1985, 1986; Tada, 1983; } \\
\text { Takaoka et al., 1984; World Health Organization, } 1982\end{array}$ \\
\hline S. minusculum of amazonicum complex* ${ }^{*}$ & Brazil & Rassi, 1974 \\
\hline S. minusculum ${ }^{*}$ & Brazil & Shelley at a1., 1982 \\
\hline S. pseudosanguineum syn. & Venezuela & Ramirez Perez \& Peterson, 1981 \\
\hline S. sanchezisyn. & Venezucla & Ramirez Perez et al., 1982; Yarzabal et al., 1983 \\
\hline S. sanguineum ${ }^{*}$ & Brazil & Shelley et al., $1979 \mathrm{a}, \mathrm{b}, 1980$ \\
\hline S. sanguincum group forms $A \& C$ & $\begin{array}{l}\text { Brazil } \\
\text { Venezuela }\end{array}$ & Tidwell et al., $1981 \mathrm{a}$ \\
\hline S. simulium sp. A & Brazil & Shelley et al., 1976 \\
\hline
\end{tabular}

*Denotes misindentification. 
In 1983 Ramirez Perez synonymised $S$. yarzabali with $S$. incrustatum and in more recent reviews (Ramirez Perez, 1984, 1985, 1986) cites $S$. incrustatum as a vector of $O$. volvulus in Venezuela. We believe their synonymy to be premature based on an examination of reared $S$. incrustatum topotypes and $S$. yarzabali paratypes and therefore revalidate $S$. yarzabali. The former species possesses hairing on the subcostal wing vein and is zoophilic whereas the converse is true for $S$. yarzabali. Furthermore, biting females of $S$. yarzabali and $S$. limbatum are indistinguishable, separation only being possible on reared material using the configuration of the pupal gill. Our reared material from within the focus at Auaris is insufficient to establish whether both species are present. New material therefore needs to be collected for detailed morphological and cytological analyses in order to establish the relationship between zoophilic $S$. incrustatum from southern Brazil, anthropophilic $S$. yarzabali from the highland areas of the focus and $S$. limbatum, a common anthropophilic species in the savanna adjacent to the focus. The suspected role of $S$. yarzabali as a vector of onchocerciasis in the highland areas of the focus still requires con. firmation.

\section{RESUMO}

Identificação das espécies vetoras (Diptera: Simuliidae) de oncocercose humana no foco da Amazônia do Brasil e da Venezuela - Revisa. mos as posições taxonômicas de três espécies de simulídeos da Amazônia, Simulium guianense Wise, $S$. oyapockense Flock \& Abonnenc e $S$. yarzabali Ramirez Perez.

Sinonimizamos $S$. cuasisanguineum Ramires Perez, Yarzabal \& Peterson com S. oyapockense, revalidamos $S$. yarzabali que estava em sinonimia com $S$. incrustatum.

Discutimos os papéis destas três espécies na transmissão de oncocercose e mansonelose humana na Amazônia.

Palavras-chave: Simuliidae -- espécies vetoras de oncocercose - Amazônia

\section{ACKNOWLEDGFMFNTS}

We thank Dr. Sandoval of SUCAM, Roraima, for facilitating field work and Mr. P. Garritano and Miss C. Couch for their tecnical assistence.

\section{REFERENCES}

CERQUEIRA, N.L., 1959. Sobre a transmissāo da Mansonella ozzardi. J. Bras. Med., I : 885-914.

DANG, P.T. \& PLTLRSON, B.V., 1980. Pictorial keys to the main species and species groups within the Simulium domnosum Theobald complex occuring in West Africa (Diptera: Simulidae). Tropenmed. Parasit., $31: 117 \cdot 120$.
FLOCH, H. \& ABONNENC, E. 1946. Simulides de 1a Guyane Française (II). $S$. cauchense n. sp., $S$. oyapockense n. sp., $S$. iracouboense. Publ. Inst. Pasteur Guyane Franç., 137 : 1-19.

GOELDI, E.A., 1905. Os mosquitos no Pará. Mem. Mus. Paraense Hist. Nat. Ethnogr., 4 :1-154.

MEREDITH, S. E. O.; CHEKE, R.A. \& GARMS, R., 1983. Variation and distribution of forms of Simulium soubrense and $S$. sanctipauli in West Africa. An. Trop. Med. Parasitol, $77: 627-640$.

MORAES, M.A.P.; SHELLEY, A.J.; CALHEIROS, L. B. \& PORTO, M.A.S., 1979. Estado atual do conhecimento sobre os focos brasileiros de oncocercose. An. Brasil. Dermat., 54 :73-85.

MORAES, A.P.A.; SHELLEY, A.J. \& LUNA DIAS, A.P.A., 1985. Mansonella ozzardi no Território Federal de Roraima, Brasil: distribuiçāo e achado de um novo vetor na área do Rio Surumu. Mem Inst. Oswaldo Cruz, $80: 395400$.

NATHAN, M.B.; TIKASINGH, E.S. \& MUNROE, P., 1982. Filariasis in Amerindians of Western Guyana with observations on transmission of Mansonella ozzardi by a Simulium species of the amazonicum group. Tropenmed. Parasitol., 33 :219-222.

PY-DANIEL, V., 1983. Caracterização de dois novos subgeneros em Simuliidae (Diptera: Culicimorpha) Neotropical. Amazona, $8: 159-223$.

RAMIREZ PEREZ, J., 1971. Distribucion geografica y revision taxonomica de los Simulidos (Diptera: Nematocera) de Venezuela con descripcion de diez especies nuevas. Acto Biol. Venez., 7 :271-371.

RAMIREZ PLREZ, J., 1980. Descripcion de cuatro nuevas especies de Simulium Latreille, 1802 (Diptera, Simuliidae) de la region amazonica de Venezucla. Bol. Dir. Malariol. Y San. Amb., 20 :59-69.

RAMIRFZ PlREZ, J., 1983 Los jejenes de Venezuela. Simposio de oncocercosis americana. Caicet. Puerto Ayacucho, 15-17 Octubre, 1983 (iiit) $156 \mathrm{pp}$.

RAMIREZ PEREZ. J., 1984. Vectores de la oncocercocis humana en Venezuela. Bol. Dir. Malariol. y San. Amb., $24: 79-94$.

RAMIRLZZ PliREZ, J, 1985. Vectores de la oncocercosis humana en la region neotropical Bol of. Sanit. Panam., $98: 117-135$.

RAMIRLZZ Pl:RLZ, J. 1986. Human onchocerciasis foci and vectors in the American tropies and Subtropics. Bull PAHO, $20: 381402$ [Amended linglish version of Ramirez. Perez, 1985].

RAMIRLZ PIREZ, J. \& PLTERSON, B.V.. 1981. Estudio del complejo Simulium amazonicum-sanguineum en Venezucla. Descripcion de tres nuevas especies. Bol. Dir. Malariol. y San. Amb., 21 :151-160.

RAMIRLZ PERLZ, J.: YARZABAL, L. \& PLTERSON, B., 1982. La simuliofauna del Territorio Federal Amazonas (Venezucla). Publication Cientitica, 1. Ediciones Proicet Amazonas, Caracas, Venczuela, $104 \mathrm{pp}$.

RASSI, I., 1974. Assessoria para a pesquisa e o controle da oncocercose no Brasil. 18 de abril-18 de junho de 1974. $34[+30]$ pp. Pan American Health Orgranization. Unpublished document Brasil $-1000 / \mathrm{D}$ (mimeographed).

RASSI, L; ; LACI:RDA, N.; GUIMARĀES, J.A.; VULCANO, M.A.; RAMIREZ PERFZ, J゙: \& RAMIREZ, A., 1975a. Informe preliminar sobre un nuevo vector de la oncocercosis en las Americas: el Simu- 
lium amazonicum (Goeldi, Lutz, 1910 y 1917). Bol. Of. Sanit. Panam., $79: 136-138$.

RASSI, L.; LACERDA, N.; GUIMARÄLS, J.A.; VULCANO, M.A.; RAMIREZ PEREZ, J. \& RAMIRLZ, A., 1975 b. Preliminary report on a new vector of onchocerciasis in the Americas: Simulitum amazonicum (Goeldi, Lutz, 1910 and 1917). PAHO, Bull, $9: 10-12$

RASSI, E. \& MONZON, H. 1981. Lesiones dermatologicas en el nuevo foco de oncocercosis (Ceguera de los rios) en el area fronteriza con Brasil del Território Federal Amazonas, Venezuela. Gac. Med. Caracas, $89: 151-165$.

RASSI, E.; MONZON, H.; CASTILLO, M.; HERNANDEZ, I.; RAMIREZ PEREZ, J. \& CONVIT, J., 1977. Discovery of a new onchocerciasis focus in Venezuela. PAHO, Bull, $11: 41-64$.

RASSI, E.; MONZON, H.; CASTILLO, M.; HERNANDEZ, I.; RAMIREZ PEREZ, J. \& CONVIT, J., 1978. Descubrimiento de un nuevo foco de oncocercosis en Venezuela. Bol. Of. Sanit. Panam., 84 :391-395 [Spanish translation of Rassi et al. (1977)].

SHELLEY, A.J.; LUNA DIAS, A.P.A. \& MAIA-HERZOG, M., 1984. New specific sy nonymy in Neotropical Simulim s. 1. (Diptera: Siminuliidae), Mem. Inst. Oswaldo Cruz, 179:143-161.

SHELLEY, A.J.; LUNA DIAS, A.P.A. \& MORAES, M.A.P., 1980. Simulium species of the amazonicum group as vectors of Mansonella ozzardi in the Brazilian Amazon. Trans. R. Soc. Trop. Med. Hyg., $74: 784-788$.

SHELLlY, A.J.: LUNA DIAS, A.P.A.; MORAES, M.A.P. \& PROCUNIER, W.S., (in press). The status of Simulium oyapockense and $S$. limbatum as vectors of human onchocerciasis in Brazilian Amazonia. Med. Vet. Ent.

SHELLEY, A.J.; NUNES DE MFLLO, J.A.S. \& REES, R.G.O., 1976. Observaçôes sobre a transmissão de oncocercose no rio Toototobi Amazonas, Brasil. Acta Amazonas, 6 :327-334.

SHILLEY, A.J.; PINGIR, R.R. \& MORAES, M.A.P., 1982. The taxonomy and medical importance of Simulium amazonicum Goeldi (Diptera: Simuliidac), with a review or related species. Bull. Brit. Mus. (Nat. Hist.) Ent. Ser., $44: 1-29$.
SHELLEY, A.J.; PINGER, R.R.; MORAES, M.A.P.; CHARLWOOD, J.D. \& HAYES, J., 1979a. Vectors of Onchocerca volvulus at the river Toototobi, Brazil. J. Helminth., $53: 41.43$.

SHELLEY, A.J.; PINGER, P.R.; MORAES, M.A.P. \& HAYES, J., $1979 \mathrm{~b}$. concentration of microfilariae of Onchocerca volvulus by Simulium sanguineum during feeding; use in mapping parasite distribution in the skin. Jour. Med. Entomol, $16: 48-51$.

TADA, I. (ed.), 1983. A. comparative study on onchocerciasis between south and central America. Shimoda Printing \& Co. Ltd., Matsubase, Shimomashiki-gun, Kumamoto, Japan [xv+] 79pp $[+v]$.

TAKAOKA, H.; SUZUKI, H.; NODA, S.; TADA, I.; BASANEZ, M.G. \& YARZABAL, L., 1984. Development of Onchocerca volvulus larvae in Simulium pintoi in the Amazonas region of Venezuela. Am. J. Trop. Med \& Hyg., 33 :414-419.

TIDWELL, M.A.; PETERSON, B.V.; RAMIREZ PEREZ, J.; TIDWELL, M. \& LACEY, L.A., 1981. Notas y claves preliminares de los jejenes neotropicales pertenecientes a los grupos Simulium amazonicum y $S$. sanguineum (Diptera: Simuliidae) incluyendo los vectores de Onchocerca volvulus y Mansonella ozzardi. Bol. Dir. Malariol. y San. Amb., 21 :79-88.

TIDWELL, M.A. TIDWELL, M.A. \& MUNOZ DE HOYOS, P., 1980. Development of Mansonella oz. zardi in a black fly species of the Simulium sanguineum group from eastern Vaupes, Colombia. Am. J. Trop. Med. Hyg., $29: 1209-1214$.

WISE, K.S., 1911. The Simuliidae of British Guiana. Timehri, $I: 248-254$.

WORLD HEALTH ORGANIZATION, 1982. Report of a informal workshop on the taxonomy of South American Simuliidae of medical importance. Unpublished document. TDR/FILL/SIM/82.3. 13 pp. (mimeographed).

Y ARZABAL, L.; BASANEZ, M.G.; RAMIREZ PEREZ, J.; RAMIREZ A.; YARZABAL, A. \& BOTTO, C., 1983. Infeccion natural y experimental de Simulim sanchezi por Manzonella ozzardi en El Orinoco Medio, Venezuela. pp.41-48 in "Las filariasis Humanas en el Territorio Federal Amazonas (Venezuela)". Publicacion Cientifíca no 2, $159 \mathrm{pp}$. Proicet Amazonas, Venezuela. 